\author{
Barış Toptaş \\ Adıyaman Üniversitesi, btoptas@hotmail.com, Adıyaman-Turkey \\ Canan Çeşit \\ Adıyaman Üniversitesi, canancstehotmail.com, Adıyaman-Turkey
}

\title{
http://dx.doi.org/10.12739/NWSA.2014.9.2.D0149
}

\section{CARL CZERNY OP.599 ETÜT KİTABINDA SOL EL EŞLİK YAPILARININ İNCELENMESİ \\ ÖZET}

Piyanoda etkili bir öğrenmenin gerçekleşmesi için gereken en temel öğelerden biri çalışılan etütlerdir. Bu düşünce ile çalışmada, piyano eğitimi sürecinde sıkça kullanılan etüt kitaplarından biri olan Czerny Op. 599 (Czerny 100) etüt kitabinda bulunan etütlerin sol eldeki işlevselıiği araştırılmıştır. Bu etüt kitabı, piyano eğitimi sürecinin ilk yıllarında piyano öğretmenleri tarafından öğrenciye belirli teknik kazanımları sağlamak için kullanılmaktadır. Çalışmada, bu kitabın kulanım amaçları konusunda öğrencileri bilinçlendirmek amaçlanmıştır. Bu doğrultuda Czerny Op.599 kitabı incelenmiş ve 11 farklı yapı tespit edilmiştir. Elde edilen 11 farklı yapının farklı akor konumlarında oluşumları incelenmiştir. Ayrıca yapıların farklı düzeyde birkaç piyano eserindeki yansımaları ve bu eserlerdeki kullanılma biçimlerine örnekler verilmiştir. Çalışma sonucunda, Czerny Op.599 kitabından elde edilen kazanımların sadece bu kaynak kitap için değil aynı zamanda ileriki dönemlerde çalışılacak olan birçok piyano eserine de katkıda bulunacağı düşüncesine ulaşılmıştır.

Anahtar Kelimeler: Czerny, Etüt, Analiz, Piyano, Piyano Eğitimi

\section{EXAMINATION OF STRUCTURES LEFT HAND CARL CZERNY OP.599 STUDY IN THE BOOK}

\section{ABSTRACT}

For the realization of an effective learning at piano one of the most basic elements are studied surveys. With this idea in the study, In the process of studying the piano is one of the frequently used Czerny etude books Op. 599 (Czerny 100) study of books found in the study was to investigate the functionality of the left hand. This studies book, in the early years of piano training process of students by teachers of piano is used to provide specific technical achievements. In the study, about the intended use of this book is intended to educate students. In this respect, the book examined Czerny Op.599 and 11 different structures have been identified. 11 different structures obtained at positions different chord formations were examined. In addition, the use of structures at different levels of piano works are illustrated. Also structures at different levels as reflected in several piano works and These works are examples of the use forms. As a result, the gains from Czerny Op.599 books only, but also for this resource book to be studied in the future will contribute to the thinking of many piano works has been reached.

Keywords: Czerny, Etude, Analyze, Piano, Piano Education 


\section{GIRIŞ (INTRODUCTION)}

Eğitimde, bireye kazandırılmaya çalışılan hedef davranışa yönelik olarak yaptırılan çalışmalar hedeflenen amaca ulaşmanın en temel yolu olması bakımından önemlidir. Bu çalışmalar, öğretilmek istenen konuyla ilgili temel becerileri kazandırabilmek veya öğrenilen davranışların kalıcılığını ve sürekliliğini sağlamak amacıyla eğitimin her alanında kullanılmaktadırlar. Alıştırma, ya da etüt olarak adlandırılan bu çalışmalar, etkili bir öğrenmenin gerçeklemesi için gerekli olan en temel öğeler arasında bulunmaktadır.

Teknik anlamı ile etüt bir konu üzerinde ön çalışma yapma, uzmanlaşmak istenilen konuda var olan bazı eksikliklerin üzerinde sürekli olarak durma şeklinde tanımlanabilir. Çalışma sahalarının birçoğunda etüt yapma kavramı kullanılabilmektedir. Etüt, müzik eğitiminin içerisinde özellikle de çalgı eğitimi boyutunun vazgeçilmez öğelerindendir. Agay'a göre (1981:185) etüt, çalıcının teknik kabiliyetini geliştirmek amacıyla tasarlanmış ve genellikle bir motif veya figür üzerine yazılmış enstrüman parçasıdır (Akt: Öztürk, 2007:242).

"İcracının çalgısı üzerindeki teknik gelişiminin să̆lanması amacıyla yaratılan bir özel kompozisyon" olarak tanımlanabilen etüt kavramı (Scholes, 1992:336; Sadie, 1995:304:Akt: Cüceoğlu, Berki, 2007:228), genel olarak müzik eğitimi alanında müzisyenin teknik açıdan gelişimini sağlamaya yönelik olarak oluşturulan çalışmalar olarak tanımlanırken, müzikal yönden gelişimini sağladığı da bilinmektedir.

Müzik eğitiminde belirli zorlukları yenmek üzere hazırlanan etütler, çalgı tekniğini ustalık düzeyinde geliştirmeyi öngören, aynı zamanda müzikal değerlere de ağırlık veren araştırmacı nitelikte olgun alıştırma parçalarıdır. Etütlerin belirli bir formu yoktur. İi ya da üç bölümlü şarkı, bazen de "Rondo" formunda yazılmışlardır. Ancak çoğunluğu özgür formdadır. 15. yüzyılda org öğretiminde kullanılmak üzere yazılan eğitsel parçalar ilk etüt örnekleri arasında kabul edilir. Bu örnekler süreç içerisinde gelişim göstererek 18. yüzyılda kompozisyon değeri taşıyan kısa eserlere (prelude, toccata ve benzer özgür formlu parçalar) dönüşmüştür (Say, 2002:189-190). Etütler hemen her çalgıda olduğu gibi piyano eğitimi ve repertuarının da vazgeçilmez öğeleri arasındadır.

Piyanonun tarihsel süreci içerisinde etütlerin uzun bir geçmişe ve önemli bir yere sahip olduğu açıkça görülmektedir. Bu tarihsel süreç içerisinde bestelenen etütlerin bir kısmı etüt olma özelliklerinin ötesinde, bestecisinin ve icracısının sanatsal performansını sergileyebilmesine olanak tanıyan gösterişli eserler olma özelliği taşımışlardır (Tufan, 2004:76).

Pamir; "Çă̆daş Piyano Eğitimi" adlı çalışmasında (s.130) etütlerin, müzik edebiyatında rastlanan bütün güçlükleri, sistemli bir şekilde işledikleri ve bunları bir bütün içinde elde etmenin piyaniste yeni bir deneyim kazandırdığı için yaralı olduğu görüşünü belirtmiştir.

Etütlerin, müzisyenin belli konulardaki eksiklerini gidermesinin, teknik ve müzikal anlamda gelişimini sağlamasının hedeflenerek oluşturuldukları düşünüldüğünde alana sağladıkları katkılar ile alan açısından gerekliliği ve önemi ortaya çıkmaktadır. Etütlerin müzisyene sağlayabileceği katkıların ve oluşturulma amaçlarının fark edilebilmesi ise bu çalışmaların incelenerek çözümlemelerinin yapılmasını gerektirmektedir.

Müzik oluşturma süreçlerinin (besteleme, seslendirme/yorumlama ve doğaçlama) her birinde analitik yaklaşım zorunludur. Özellikle seslendirme/yorumlama gibi performansa dayalı müziğin, kişinin 
bilişsel, duyuşsal, sezişsel ve devinişsel alanlarının tümünü kullandırmak zorunda bırakması, bu alanların birbirine dayalı etkileşiminin yüksek düzeyde olmasını gerektirmektedir. Daha etkili bir seslendirmeye neden olacak söz konusu bu yüksek düzeydeki etkileşimin gerçekleştirilebilmesindeki ön koşul, çalışılan etüt ya da eserin (düzeyi ne olursa olsun) genel müzikal doğrular ve piyano eğitiminin beklentileri ekseninde hem teknik hem de müzikal disiplinler açısından analizinin yapılmasıdır (Bağçeci, 2003:162).

Bu doğrultuda; piyano eğitimi sürecinde öğrenilen her parça, etüt ve bunlar içerisindeki belirli kalıplar hem öğretmen hem de öğrenci tarafından iyi analiz edilmelidir. Piyano eğitiminde öğrenilen her türlü bilginin sadece $\circ$ an için değil ileriki aşamalarda da kullanılabileceği unutulmamalıdır. Piyano eğitiminde öğrenilen tüm teorik ve pratik kazanımlar daima bir sonraki çalışmalar için ışık tutmaktadır.

Piyano eğitiminde öğrenilen her bilgi geleceğe yönelik birer kazanımdır. Piyanodaki teknik gelişimi sadece etütler değil çalışılan eserlerde destekler. Özellikle çalışılan piyano parçalarındaki önemli yapılara dikkat edilmelidir. Parça içerisinden seçilen küçük yapıların etüt olarak geliştirilip çalınması da piyano eğitiminin içerisinde oldukça önemlidir.

Piyano eğitimi sırasında öğrencilerin hangi etüt ve alıştırmaları kullanmaları gerektiği konusunda bilgilendirilmelerinin yanında bu etütlerin amaçları ve nasıl çalışılacağı konusunda da fikir sahibi olabilmeleri önemlidir. Bu sebeple çalışılan etütler üzerinde çözümlemelerin yapılması, hem öğrenci hem öğretme açısından önemli bir ihtiyaçtır.

Piyano öğrencileri için en güç şeylerden biri etüt ve alıştırmaların nasıl çalışılacağını öğrenmektir. Doğru alıştırma fiziksel eforla birlikte, zihin ve kulağın aktif katılımını da gerektirmektedir. Eğer zihin etkili bir şekilde bu işe odaklanırsa, yapılan çalışmalarda sıkıcı olmayacaktır (Ercan, 2008:95). Bu nedenle çalışılan etütler üzerinde yapılan analizler de önem taşımaktadır.

"Teknik anlamda piyano eğitiminde en önemli gelişimi sağlayan etütler, gerek güçlük düzeyi, gerek amacı, gerekse uygulanma biçimi itibariyle eğitim sürecinde oldukça etkin bir şekilde kullanılmaktadır. Etütıer yazılma amacı itibariyle çeşitli kategorilere ayrılmaktadır. Bu kategoriler içerisinde eğitim ve teknik gelişim amacıyla yazılmış olan etütlerin incelenmesi ise ayrı bir süreç olarak görülmektedir. Analiz yolu ile daha iyi tanınan etütlerin algılanışı ve benimsenmesi de kolaylaşır. Özellikle eğitim amaçlı etütlerin incelenmesi, analiz edilmesi ve bu gözden geçirme süreçlerinden faydalı çıkarımlarda bulunulması, şüphesiz sürece olumlu katkılar sağlayacaktır" (Kurtuldu, 2009,29).

Ülkemizde müzik eğitimi alanında etüt analizi olarak; keman (Delikara, 2013), flüt (Cüceoğlu, Berki, 2007), şan (Temiz, 2006) gibi farklı alanlarda yapılan çalışmaların yanında piyano için Carl Czerny etütleriyle ilgili yapılan çalışmalar (Öztürk, 2007; Kurtuldu, 2009; Umuzdaş, 2012) örnek verilebilir.

Piyano eğitimi alanına yönelik olarak pek çok eser ve özellikle etüt çalışmaları olan Carl Czerny'nin piyano eğitimine yönelik sıkça kullanılan etüt metotları şunlardır (Öztürk, 2007:243).

- Op. 299, Ecole de velocite

- Op. 337, Etudes (Tägliche Studien)

- Op. 409, Etudes speciales: 50 grandi studi di perfezionamento per piano forte

- Op. 495, Etudes progressives et brillantes.

- Op. 599, Etudes, (Erster Wiener Lehrmeister im Pianofortespiel) 
- Op. 699, Etudes, (Kunst der Fingerfertigkeit)

- Op. 718, 24 Etudes, (Etüden für die linke Hand)

- Op. 740, Etudes, (The Art of Finger Dexterity)

- Op. 849, 30 Etudes, introduction to op. 299

Yukarıda adı geçen kitaplar öğrenciye piyano eğitimi sürecinde önemli katkılar sunmaktadır. Önemli olan durum ise kitapların tümünün çalınması değil neler kazandırdıklarının bilinmesidir.

\section{2. ÇALIŞMANIN ÖNEMI (RESEARCH SIGNIFICANCE)}

Bu çalışmanın amacı, piyano eğitimi sürecinin ilk yıllarında bu etüt kitabının sol el konumları açısından incelenerek başlangıç piyano eğitimi sürecinde öğrencilere katkı durumlarını tespit etmektir. Yapılan bu tespit sonucunda elde edilen bulgulardan yola çıkarak orta ve ileri düzey piyano seviyelerinde bu yapıların nasıl kullanıldıklarını açıklayarak daha sonraki benzer çalışmalara ışık tutmaktır. Ayrıca bu çalışma ile öğrencileri, piyano eğitimleri esnasında sıklıkla kullandıkları etüt kitapları ve alıştırmalarının nasıl verimli kullanacakları hakkında bilinçlendirmek amaçlanmıştır. Bu çalışma; piyano eğitiminde kullanılan Carl Czerny'nin Op.599 Etudes Kitabı'nın sol el konumları açısından incelenerek analizlerinin yapılması ile kullanım amaçlarının fark edilmesi ve öğrencilerin bu amaçları kazanmalarını sağlaması bakımından önem taşımaktadır. Bunun yanında öğrenilen teknik kazanımların doğru bir şekilde anlaşılması ve ileriki dönemlerde de bu tür yapilarla karşllaşılabileceğinin bilinmesi piyano eğitiminde hem öğretmen hem de öğrenci verimliliği açısından önemlidir.

\section{YÖNTEM (METHOD)}

\subsection{Verilerin Toplanması (Data Collection)}

Çalışma kapsamında ilk olarak piyano eğitimi ve bu eğitim içerisindeki etüt, egzersiz konularında literatür taraması yapılmış, hazırlanan konu için gerekli kaynaklara ulaşılmaya çalışılmıştır. Ele alınan Czerny'nin Op.599 Etudes kitabında bulunan 100 etüt üzerinde gerekli çalışmalar yapılarak sol elde kullanılan 11 farklı yapı tespit edilmiştir. Tespit edilen yapıların orta ve ileri düzey piyano eserlerinde nasıl kullanıldıklarına ilişkin tarama yapılmıştır.

\subsection{Sinırlilıklar (Limitations of the Study)}

Çalışma kapsamında Carl Czerny'nin Op.599 Etudes kitabında bulunan 100 etüdün her türlü sol el figürü detaylıca incelenmiştir.

\section{BULGULAR VE YORUM (FINDINGS AND INTERPRETATION)}

Yapılan araştırma ve inceleme sonucunda elde edilen bulgular ve bu bulguları destekleyici örnekler orta ve ileri düzey piyano eserlerinden faydalanılarak ayrıntılı olarak açıklanmıştır. Bu örnekler yapıyla kimi zaman birebir örtüşebilmektedir, kimi zaman da yapıyla birebir örtüşme sağlanmamasına rağmen büyük oranda benzerlik taşımaktadır. Tablolardaki frekans değeri ilgili yapının kitap içerisinde kaç kez kullanıldığını, yüzde değerleri ise yapının yüzdelik oranını vermektedir. Frekans (f), Yüzde (\%) işaretleri ile gösterilmiştir. 
Tablo 1. C. Czerny Op.599'da kullanılan sol el yapıları (Table 1. Structures used at C. Czerny Op.599 left hand)

\begin{tabular}{|c|c|c|c|c|c|c|c|}
\hline \multicolumn{2}{|c|}{ Yapilar } & f) & 응 & \multicolumn{2}{|r|}{ Yapılar } & \multirow{2}{*}{$\begin{array}{l}\text { f) } \\
86\end{array}$} & \multirow{2}{*}{$\begin{array}{l}\left.\frac{\circ}{0}\right) \\
\frac{\circ 5}{0}\end{array}$} \\
\hline 1 & $\frac{2}{3}$ & 563 & $\div 32$ & 7 & $\frac{7}{b \cdot 0}$ & & \\
\hline 2 & $\frac{9+2+2}{6-2}$ & 414 & $\div 24$ & 8 & $\frac{6 \ldots}{2 \ldots}$ & 83 & $\div 5$ \\
\hline 3 & $\frac{1}{b \cdot a c}$ & 149 & $\div 9$ & 9 & $\frac{7}{6 \cdot 2}$ & 49 & $\div 3$ \\
\hline 4 & $\operatorname{lom}_{0}^{3}{ }_{0}^{3}$ & 147 & $\div 8$ & 10 & $\frac{1+0}{0}$ & 22 & $\div 1$ \\
\hline 5 & $\frac{1}{6}+2,2$ & 115 & $\div 7$ & 11 & $\frac{1}{e \cdot c}$ & 20 & $\div 1$ \\
\hline 6 & $\frac{6^{2}={ }^{2} \neq}{1}$ & 89 & $\div 5$ & & lel Toplam & 1737 & 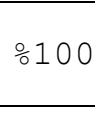 \\
\hline
\end{tabular}

Yukarıda Tablo 1'de, Czerny Op.599'da kullanılan 11 farklı sol el yapısı görülmektedir. Bu 11 yapıdan bir ve ikinci yapılar kitap içerisinde en çok kullanılanlar olarak tespit edilmiştir. Kitap içerisinde ikinci yapının farklı ölçü sayılarıyla da (ör: 3/8'lik, 3/4'lik, 6/8'lik) kullanımlarına sıkça rastlanmıştır. Bu yapının farklı ölçü sayılarında kullanılmasına rağmen yapının şeklinin değişmediği gözlemlenmiştir. Aynı durum dördüncü yapı için de geçerlidir. Bu yapının da 3/8'lik ve 6/8'lik kullanımlarının olduğu saptanmıştır.

Tablo 2. Yapı 1'in durumu

(Table 2. Status of structure 1)

\begin{tabular}{|c|c|c|c|c|c|c|c|c|c|}
\hline \multicolumn{2}{|r|}{ Yapı 1} & Şifre & (f) & $\left(\frac{\circ}{0}\right)$ & \multicolumn{2}{|c|}{ Yapılar } & \multirow{2}{*}{$\begin{array}{c}\text { Şifre } \\
\text { D6 } \\
5\end{array}$} & \multirow{2}{*}{$\begin{array}{l}(\mathrm{f}) \\
32\end{array}$} & \multirow{2}{*}{$\begin{array}{c}\left(\frac{\circ}{0}\right) \\
5,68\end{array}$} \\
\hline A & $\frac{9}{88}$ & $\mathrm{~T}$ & 184 & 32,68 & $\mathrm{~F}$ & $\frac{20}{6}$ & & & \\
\hline B & $\frac{2}{88}$ & D6 & 111 & 19,72 & G & $\frac{9}{8}$ & D7 & 24 & 4,26 \\
\hline C & $\frac{8}{8}$ & $\begin{array}{c}S 6 \\
4\end{array}$ & 66 & 11,72 & $\mathrm{H}$ & $\frac{2}{68^{\circ}}$ & D & 16 & 2,84 \\
\hline D & $\frac{}{9 \frac{8}{5}}$ & D7 & 60 & 10,66 & I & $\frac{2}{9.80}$ & $\mathrm{~T} 2$ & 8 & 1,42 \\
\hline$E$ & $\frac{2}{8}$ & D7 & 58 & 10,30 & i & $\frac{1}{98^{\circ}}$ & $\begin{array}{r}\mathrm{D} 4 \\
3\end{array}$ & 4 & 0,71 \\
\hline & & & & & To & lam & & 63 & 100 \\
\hline
\end{tabular}

Tablo 2'de, Yapı 1'in on farklı şekilde konumlandığı görülmektedir. Konumların şifreleri incelendiğinde $T$ (tonik) ve D 6 (dominant altılı) ilk iki sırada yer almıştır. T 2 ve D $4-3$ son iki sırada yer almıştır. Yapı 1'in farklı konumları diğer tonlarda da kullanılmıştır. Yapı 1'de D7 (dominant yedili) üç farklı biçimde kullanılmıştır. Burada önemli olan ton kavramından ziyade sol elde işlenme biçimleridir. Bunların yanında tablo 2'deki yapı 1'in on farklı şeklinin kitap içerisinde kullanımı sol elin gelişimi açısından oldukça önemlidir. Bu doğrultuda yapı 1'in orta düzey bir sonatinde kullanımı aşă̆ıda sergilenmiştir. 

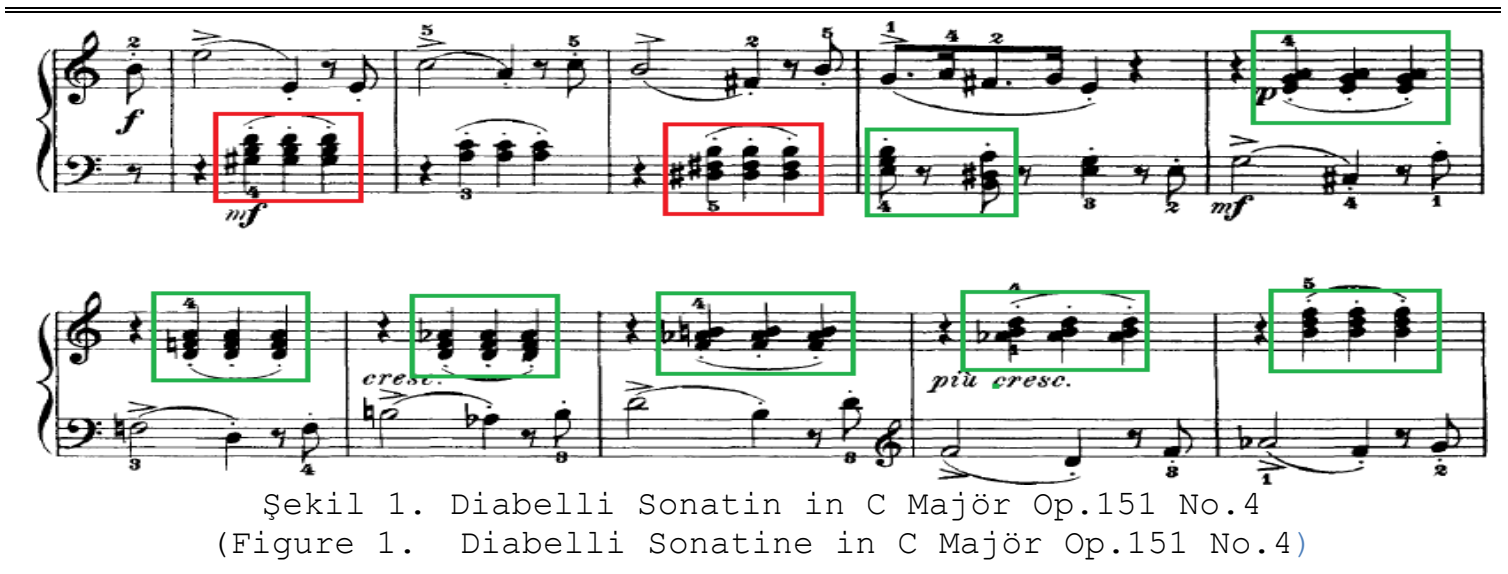

Yukarıda Şekil 1'de, Diabelli Do Majör Sonatin'i 32. ve 42. Ölçüler arası sergilenmektedir. Kırmızı alan ile işaretlenmiş bölgeler sol elde kullanilan farklı konumlardaki akor yapılarını göstermektedirler. Yeşil alanda ise akorlar sağ elde kullanllarak sol eldeki ezgiye armonik ve ritimsel eşlik yapılmıştır. Yukarıda sergilenen eserden, akorların farklı amaçlar doğrultusunda bestecinin besteleme anlayışına göre çeşitli şekillerde kullanılabildiği anlaşılmaktadır. Ek olarak bu yapı 2.yapının (tablo 3) sabit akorlarla oluşturulmuş şekli olarak da görülmektedir.
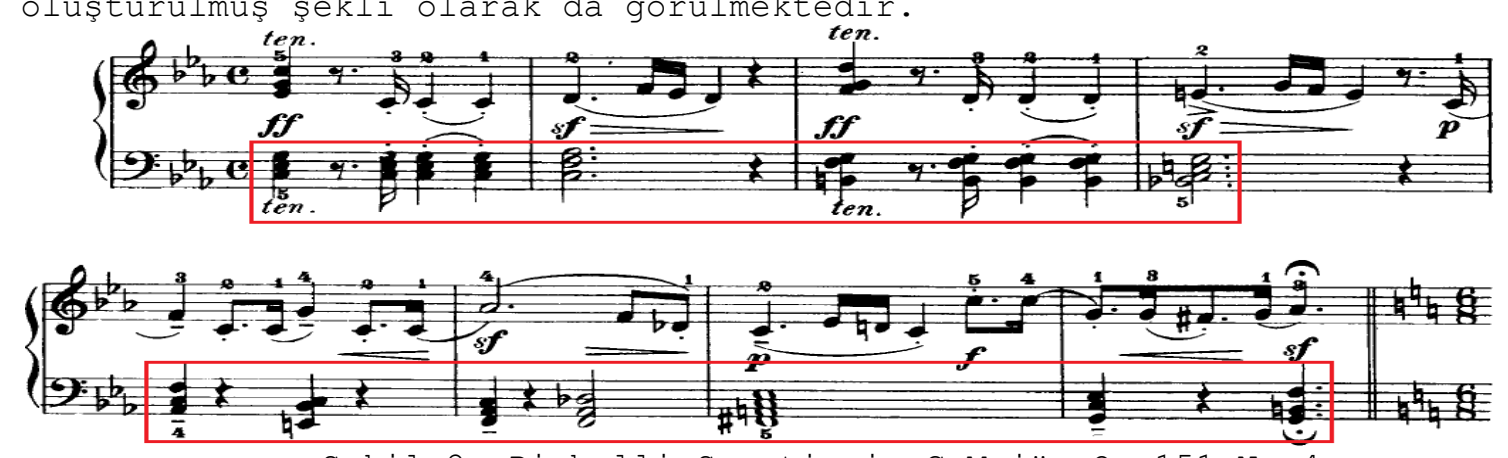

Şekil 2. Diabelli Sonatin in C Majör Op.151 No.4

(Figure 2. Diabelli Sonatine in C Majör Op.151 No.4)

Şekil 2'de de, Diabelli Do Majör Sonatin'in 2. bölümünün tamamı sergilenmektedir. Kırmızı alan ile belirtilmiş akorlar ilk ölçüden son ölçüye kadar incelendiğinde sadece akorların yürüyüşü ile eserin armonik yapısını anlaşılabilmektedir. Bu doğrultuda piyanoda akorların ne kadar önemli bir görev üstlendiği açıktır. 
Tablo 3. Yapı 2'nin durumu

(Table 3. Status of building 2)

\begin{tabular}{|c|c|c|c|c|c|c|c|c|c|}
\hline \multicolumn{2}{|c|}{ Yapı 2} & Şifre & $(f)$ & $\left(\frac{\circ}{0}\right)$ & \multicolumn{2}{|c|}{ Yapılar } & \multirow{2}{*}{$\begin{array}{c}\text { Şifre } \\
\text { D7 }\end{array}$} & \multirow{2}{*}{$\begin{array}{l}(f) \\
32\end{array}$} & \multirow{2}{*}{$\begin{array}{c}\left(\frac{\circ}{0}\right) \\
7,73\end{array}$} \\
\hline A & $\frac{7+\infty}{0+3}$ & $\mathrm{~T}$ & 224 & 54,10 & $\mathrm{E}$ & $\frac{\operatorname{tg}}{2 y}$ & & & \\
\hline B & $\frac{7=8}{102}$ & D7 & 50 & 12,07 & F & $\frac{7+20}{6 \cdot 0}$ & $\begin{array}{r}\text { S } 6 \\
4\end{array}$ & 19 & 4,59 \\
\hline $\mathrm{C}$ & $\frac{7+5}{7}$ & D7 & 43 & 10,39 & G & $\frac{6+8}{6+8}$ & $\begin{array}{r}\mathrm{D} 6 \\
5\end{array}$ & 6 & 1,45 \\
\hline D & $\frac{1}{2+:}$ & D6 & 37 & 8,94 & $\mathrm{H}$ & $\frac{2+0,0}{6+2}$ & $\begin{array}{r}\text { D6 } \\
5\end{array}$ & 3 & 0,72 \\
\hline & & & & & \multicolumn{2}{|c|}{ Toplam } & & 14 & 100 \\
\hline
\end{tabular}

Tablo 3'te, Yapı 2'nin sekiz farklı şekilde konumlandığı görülmektedir. Konumların şifreleri incelendiğinde $\mathrm{T}$ (tonik) ve D 7 (dominant yedili) ilk iki sırada yer almıştır. D 6-5 son sırada yer almıştır. Kitap içerisinde yapı 2'nin farklı konumları diğer tonlarda da kullanılmıştır. Bu yapıda D6/5 (dominant beş-altı) iki farklı biçimde, D7 (dominant yedili) ise üç farklı biçimde kullanılmıştır. Burada önemli olan ton kavramından ziyade sol elde işlenme biçimleridir. Bunların yanında tablo 3'deki yapı 2'nin sekiz farklı şeklinin kitap içerisinde kullanımı sol elin gelişimi açısından oldukça önemlidir. Yapı 2'nin orta ve ileri düzey bir eserde kullanımı aşağıda sergilenmiştir.
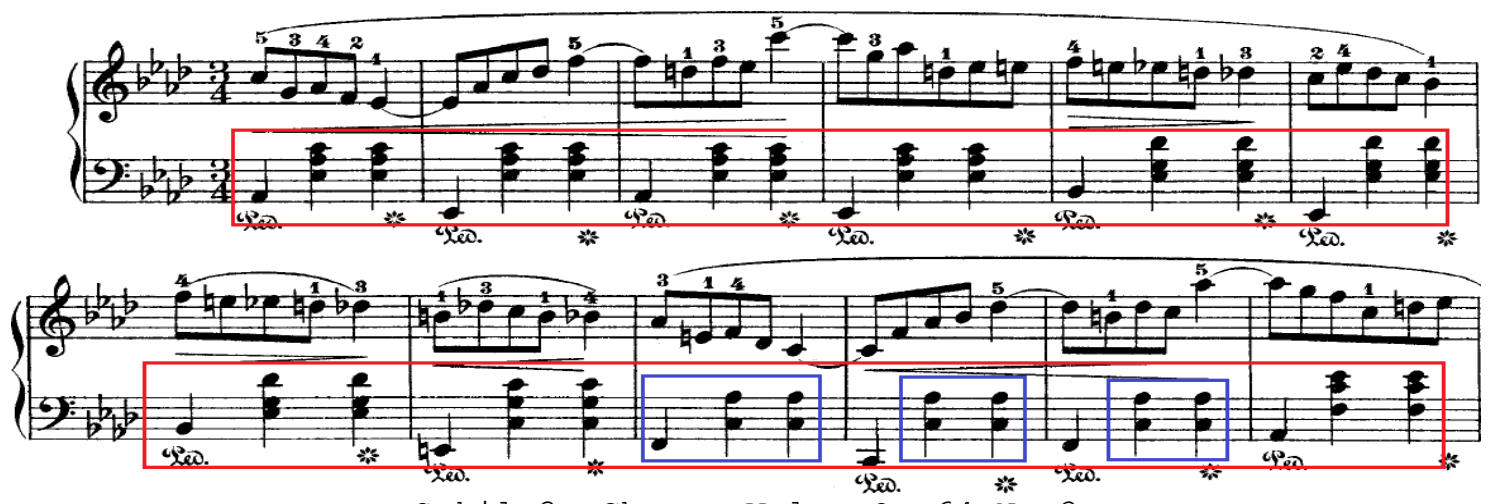

Şekil 3. Chopın Valse Op. 64 No.3

(Figure 3. Chopın Valse Op.64 No.3)

Yukarıda Şekil 3'te, Chopın Valse Op.64 No.3'ün 1. ve 12.ölçüler arası görülmektedir. Bu eserde yapı l'in farklı tonlarda ve konumlarda kullanımı kırmızı ve mavi alanlar ile belirtilmiştir. Kırmızı alanlarda ikinci ve üçüncü zamanlar üç sesten oluşmuş akor durumunda, mavi alanlarda belirtilmiş ölçülerdeki ikinci ve üçüncü zamanlar ise iki sesten oluşmuş çift ses konumundadır. 

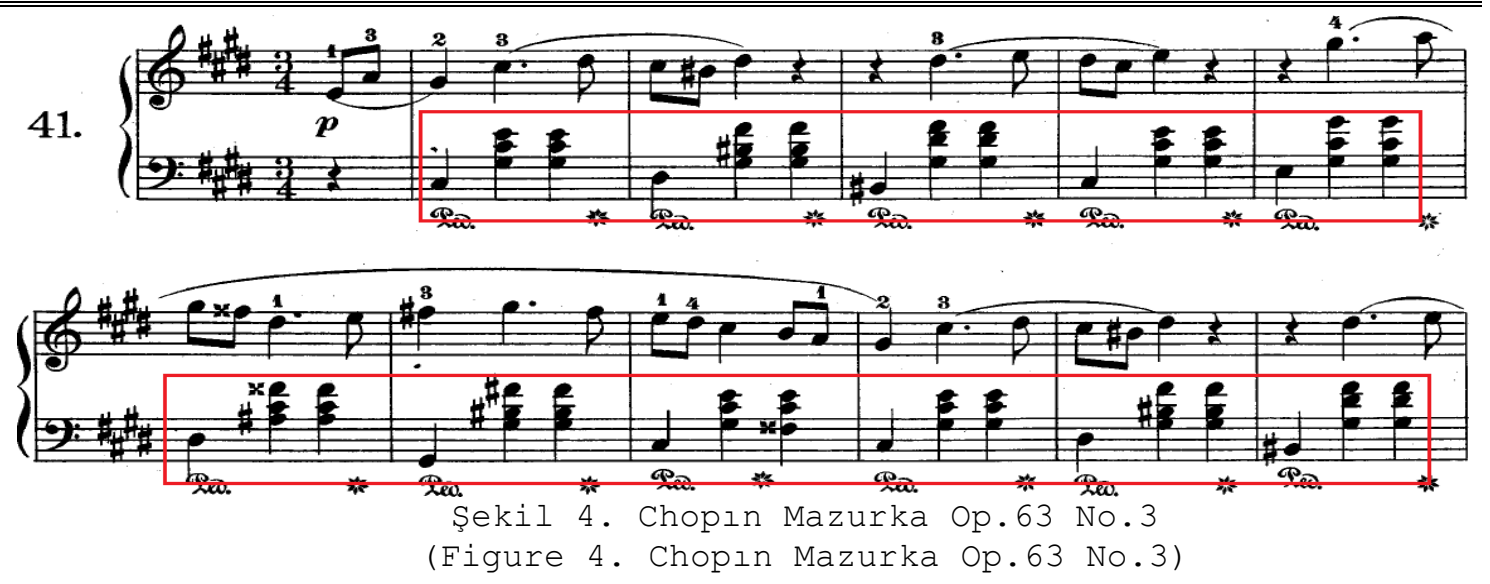

Yukarıda Şekil 3'te, Chopın Mazurka Op.63 No.3'ün 1. ve 12. ölçüler arası görülmektedir. Yine bu eserde yapı 1'in farklı tonlarda ve konumlarda kullanımı kırmızı alan ile belirtilmiştir. Yapı 2'nin temel düzey piyano eğitimi esnasında doğru bir şekilde öğrenilmesi durumunda gelecekte karşılaşılacak benzer şekilleri daha iyi uygulanabilecektir.

Tablo 4. Yapı 3'ün Durumu

(Table 4. Status of Building 3)

\begin{tabular}{|c|c|c|c|c|c|c|c|c|c|}
\hline \multicolumn{2}{|c|}{ Yapı 3} & Şifre & (f) & (\%) & \multicolumn{2}{|c|}{ Yapı 3} & \multirow{2}{*}{$\frac{\text { Şifre }}{\text { D } 7}$} & \multirow{2}{*}{$\begin{array}{l}\text { (f) } \\
10\end{array}$} & \multirow{2}{*}{$\begin{array}{c}\left(\frac{\circ}{0}\right) \\
6,7 \\
1\end{array}$} \\
\hline A & $\frac{b}{b+\ldots}$ & $\mathrm{T}$ & 80 & $\begin{array}{c}53,6 \\
9\end{array}$ & $\mathrm{D}$ & $\frac{7}{6}$ & & & \\
\hline B & 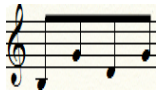 & D 6 & 22 & $\begin{array}{c}14,7 \\
7\end{array}$ & $\mathrm{E}$ & $\frac{b}{b_{0} \cdot 2 \cdot}$ & $\begin{array}{r}\text { D } 6 \\
5\end{array}$ & 8 & $\begin{array}{c}5,3 \\
7\end{array}$ \\
\hline C & $\frac{F}{b \cdot c e}$ & $\begin{array}{r}\text { S } 6 \\
4\end{array}$ & 21 & $\begin{array}{c}14,0 \\
9\end{array}$ & $\mathrm{~F}$ & 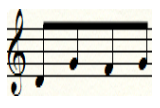 & $\begin{array}{r}\mathrm{D} 4 \\
3\end{array}$ & 2 & $\begin{array}{c}1,3 \\
4\end{array}$ \\
\hline & & & & & & Toplar & & 149 & $\% 100$ \\
\hline
\end{tabular}

Tablo 4 incelendiğinde, Yapı 3'ün 6 farklı konumunun olduğu göze çarpmaktadır. Tonik (T) konumunun kullanımının ilk sırada olduğu görülmektedir. D 4-3 konumunun ise en az kullanıldığı açıkça görülmektedir. Bu yapı özellikle en basit piyano parçalarından en üst düzey eserlere kadar sıklıkla kullanılan bir yapıdır. Ancak bu yapı Czerny Op.599'da çok fazla kullanılmamıştır. Yapı 3 için aşağıda iki farklı bestecinin piyano eserlerinden örnekler verilmiştir.

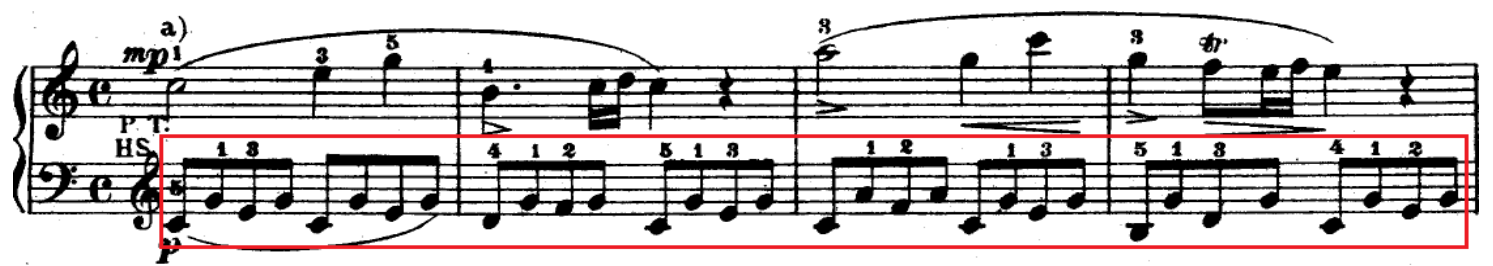

Şekil 5. Mozart Sonata in C Majör K.545

(Figure 5. Mozart Sonata in C Majör K.545)

Yukarıda şekil 5'te, Mozart Do Majör Sonat'ın 1.bölümünün (Allegro) ilk dört ölçüsü sergilenmektedir. Bu eserde sol elde kullanılan eşlik yapısına piyano edebiyatında sıkça rastlanmaktadır. Bu yapı en basit piyano etüdünden ve parçasından en üst düzey piyano 
etüt ve eserlerine kadar kullanılan oldukça önemli bir eşlik yapısıdır.

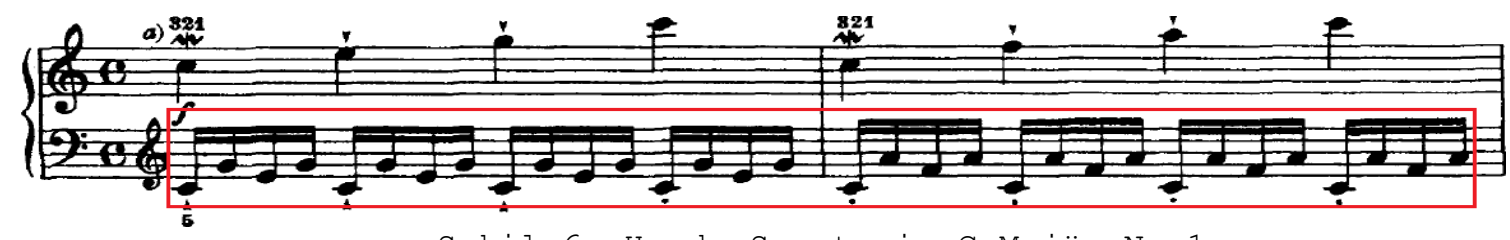

Şekil 6. Haydn Sonata in C Majör No.1

(Figure 6. Haydn Sonata in C Majör No.1)

Yukarıdaki Şekil 6'da, Haydn Do Majör Sonat'ın 1 . bölümü (Allegro) sergilenmektedir. Sol elde kırmızı alan ile işaretlenmiş bölüme bakıldığında, yapı 3'ün farklı bir ritimde kullanıldığı görülmektedir. Yine burada önemli olan yapının kendisidir. Çünkü bu yapı birçok eserde farklı ritimlerle ortaya çıkabilmektedir.

Tablo 5. Yapı 4'ün durumu

(Table 5. Status of Building 4)

\begin{tabular}{|c|c|c|c|c|c|c|c|c|c|}
\hline \multicolumn{2}{|r|}{ Yapı 4} & Şifre & (f) & (\%) & \multicolumn{2}{|c|}{ Yapı 4} & \multirow{2}{*}{$\frac{\text { Şifre }}{\text { D7 }}$} & \multirow{2}{*}{$\begin{array}{l}\text { (f) } \\
19\end{array}$} & \multirow{2}{*}{$\frac{\left(\frac{\circ}{0}\right)}{12,93}$} \\
\hline A & $\frac{b}{6 \cdot 0}$ & $\mathrm{~T}$ & 79 & 53,74 & C & $b_{7}=\infty$ & & & \\
\hline B & $\frac{F}{\sigma^{\circ}}$ & D6 & 30 & 20,41 & D & $\frac{1}{2 \cdot 2 \cdot 1}$ & $\begin{array}{r}\text { S } 6 \\
4\end{array}$ & 19 & 12,93 \\
\hline & & & & & & Toplan & & 147 & $\div 100$ \\
\hline
\end{tabular}

Yukarıdaki Tablo 5'te, Yapı 4'ün kullanımı görülmektedir. Yapı 4 konum olarak dört farklı durumda kullanılmıştır. Özellikle Tonik (T) ve D-6 (Dominant altılı) yoğun olarak kullanılmıştır. D-7 (Dominant yedili) ve S 6-4 (Subdominant dört -altı) aynı oranda kullanılmıştır. Yapı 4'ün bu üçleme özelliği orta ve ileri düzey piyano seviyesinde oldukça sık kullanılmaktadır. Bu yapı için örnekler aşă̆ıda sergilenmiştir.

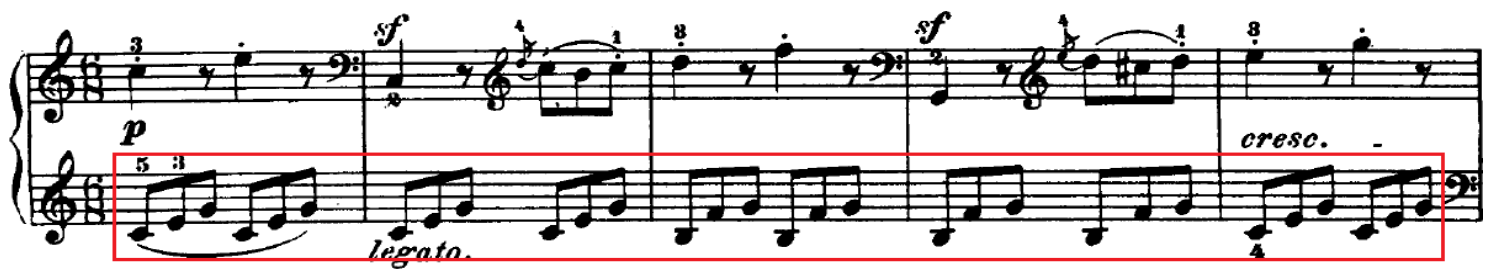

Şekil 7. Diabelli Sonatin in G Majör Op.151 No.1

(Figure 7. Diabelli Sonatine in G Majör Op.151 No.1)

Şekil 7'deki Diabelli Sol Majör Sonatin'in (2.bölüm Scherzo) sol elinde, yapı 4'ün altı sekizlik(6/8) ritim kalıbı kullanılmıştır. Kullanılan bu yapı sayesinde altı sekizlik zaman etkin bir biçimde ifade edilmiştir.

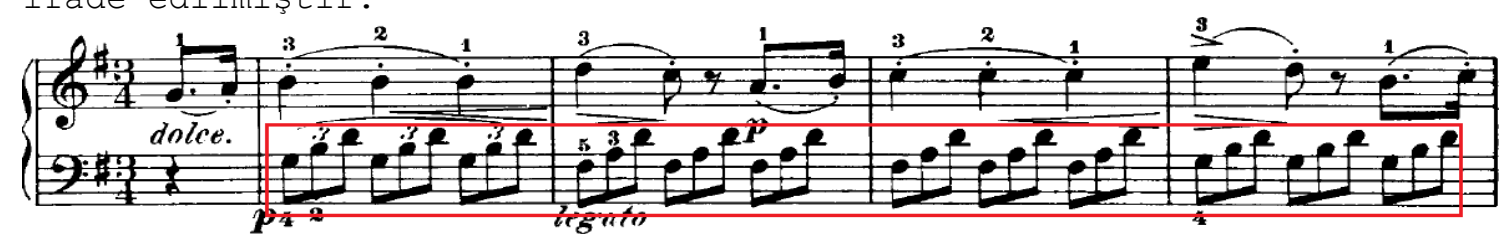

Şekil 8. Diabelli Sonatina in G Majör Op.151 No.1

(Figure 8. Diabelli Sonatine in G Majör Op.151 No.1) 
Şekil 8'de, Diabelli Op.151 No.1 Sol Majör Sonatin'in 1. Bölümü (Andante cantabile) sergilenmektedir. Bu parçanın sol elinde yapı 4'ün üçleme biçimi kullanılmıştır. Bu yapı da; temel, orta ve ileri düzey piyano eserlerinde oldukça sık kullanılan bir yapıdır.

Tablo 6. Yapı 5'in durumu

(Table 6. Status of building 5)

\begin{tabular}{|c|c|c|c|c|c|c|c|c|c|}
\hline \multicolumn{2}{|c|}{ Yapı 5} & Şifre & (f) & $\left(\frac{\circ}{0}\right)$ & \multicolumn{2}{|r|}{ Yapı 5} & \multirow{2}{*}{$\frac{\text { Şifre }}{\text { D7 }}$} & \multirow{2}{*}{$\begin{array}{c}(\mathrm{f}) \\
5\end{array}$} & \multirow{2}{*}{$\frac{\left(\frac{\circ}{0}\right)}{1,74}$} \\
\hline A & $\frac{t+2}{t_{0}=8}$ & $\mathrm{~T}$ & 65 & 56,52 & $\mathrm{~F}$ & 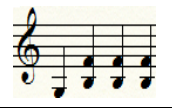 & & & \\
\hline B & $\frac{7}{b}: 5$ & D 6 & 19 & 16,52 & G & $\frac{\log }{7+8+8}$ & D7 & 2 & 1,74 \\
\hline $\mathrm{C}$ & $\frac{t_{0}+2,0}{0,0}$ & $\begin{array}{r}\mathrm{D} 6 \\
5\end{array}$ & 8 & 6,96 & $\mathrm{H}$ & $\frac{2}{2}: 3$ & T 2 & 2 & 1,74 \\
\hline D & $\frac{t+28}{2 \cdot 28}$ & $\begin{array}{r}\text { S } 6 \\
4\end{array}$ & 6 & 5,22 & I & $\frac{b}{6+8}$ & $\begin{array}{r}\text { D6 } \\
5\end{array}$ & 2 & 1,74 \\
\hline$E$ & 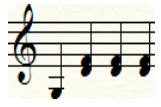 & D 7 & 5 & 4,35 & $\dot{\mathrm{I}}$ & $\frac{7+2}{6}$ & $\begin{array}{r}\mathrm{D} 4 \\
3\end{array}$ & 1 & 0,87 \\
\hline & & & & & & Topl & & 115 & $\frac{0}{8} 100$ \\
\hline
\end{tabular}

Tablo 6'da, Yapı 5'in on farklı şekilde konumlandığı görülmektedir. Konumların şifreleri incelendiğinde özellikle T (Tonik) konumunun yoğun olarak kullanıldığı, D-6 (Dominant altılı)'nın ikinci sırada olduğu görülmektedir. D 6-5 (Dominant beş-altı)'in iki farklı biçimde, D-7 (Dominant yedili)'nin ise üç farkıı konumda kullanıldığı görülmektedir. D 4-3 (Dominant üç-dört) konumunun ise en az kullanıldığı açıkça görülmektedir. Yukarıdaki yapı 5'in piyano eserlerinde ki kullanımı bazen tam benzerlik göstermemekle birlikte genel anlamda yapının taslağı fazla değişime uğramamaktadır.
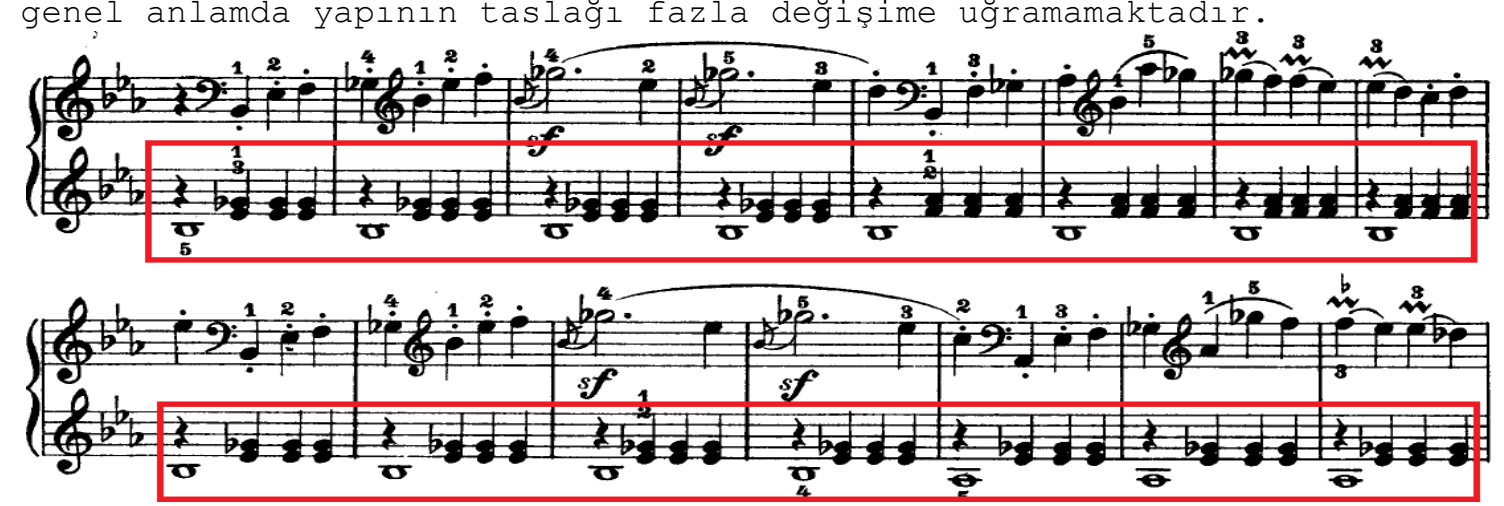

Şekil 9. Beethoven Sonata Op.13 C Minör

(Figure 9. Beethoven Sonata Op.13 C Minör)

Şekil 9'da, Beethoven Op.13 Do Minör Sonat'ın 52. ve 66. Ölçüler arası görülmektedir. Yapı 5'in sonat içerisindeki kullanımı kırmızı bölge ile belirtilmiştir. Yapı 5'in sonatta kullanılan yap ile arasındaki tek fark her ölçüdeki birinci zamanda bulunan notanın basılı kalıp ölçü boyunca uzamasıdır. Böylelikle sol elde çift partili bir duyuş elde edilmiştir. Yapı 5'in bu eserde değişikliğe uğradığı görülmektedir. Bu durum piyano eserlerinde olağandır. Bestecinin eser yazma anlayışına ya da yazdığı eserin biçimine göre kalıplaşmış bazı yapılarda çeşitlemelerin kullanımı her zaman göze çarpabilmektedir. 
Tablo 7. Yapı 6'nın durumu

(Table 7. Status of building 6)

\begin{tabular}{|c|c|c|c|c|c|c|c|c|c|}
\hline \multicolumn{2}{|r|}{ Yapı 6} & \multirow{2}{*}{$\begin{array}{c}\text { Şifre } \\
\mathrm{T}\end{array}$} & \multirow{2}{*}{$\begin{array}{l}\text { (f) } \\
44\end{array}$} & \multirow{2}{*}{$\frac{\left(\frac{\circ}{0}\right)}{49,44}$} & \multicolumn{2}{|r|}{ Yapı 5} & \multirow{2}{*}{$\begin{array}{c}\text { Şifre } \\
\text { D6 } \\
5\end{array}$} & \multirow{2}{*}{$\frac{(\mathrm{f})}{12}$} & \multirow{2}{*}{$\frac{\left(\frac{\circ}{0}\right)}{13,48}$} \\
\hline A & $\frac{6=}{7^{2}=}$ & & & & D & $\frac{}{6 \sqrt{*}=\frac{1}{7}}$ & & & \\
\hline B & $\frac{7}{7}$ & $\begin{array}{r}\text { D4 } \\
3\end{array}$ & 16 & 17,98 & $\mathrm{E}$ & $\frac{6=17}{6 \div 7}$ & $\begin{array}{r}\text { D6 } \\
5\end{array}$ & 3 & 3,37 \\
\hline C & 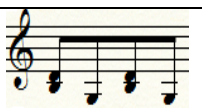 & D6 & 14 & 15,73 & & Toplam & & 89 & $\div 100$ \\
\hline
\end{tabular}

Tablo 7'de, Yapı 6'nın beş farklı şekilde konumlandığı görülmektedir. Konumların şifreleri incelendiğinde, T (Tonik) konumunun yoğun olarak kullanıldığı görülmektedir. D 4-3 (Dominant üçdört), D-6 (Dominant altılı) ve D 6-5 (Dominant beş-altı) konumlarının yakın oranlarda kullanıldıkları görülmektedir. İki farklı biçimde kullanılan D 6-5 (Dominant beş-altı) konumlarından birinin ise çok az sayıda kullanıldığı açıkça görülmektedir. Yapı 6'nın orta ve ileri düzey piyano eserlerinde kullanımına örnek aşağıda sergilenmiştir.

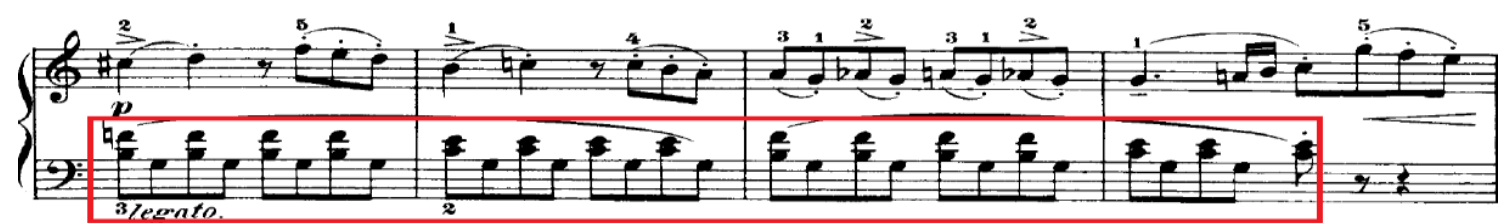

Şekil 10. Diabelli Sonatina in G Majör Op.151 No.2

Figure 10. Diabelli Sonatine in G Majör Op.151 No.2)

Şekil 10'da, Diabelli Sol Majör Sonatin'in 23. ve 26. Ölçüler arası sergilenmektedir. Eser içerisinde kullanılan yapı 6, kırmızı alan ile belirtilmiştir. Ölçüler sırasıyla 1. ölçü D6/5, 2. ölçü T6/4, 3. ölçü D6/5, 4. Ölçü T6/4 şeklinde konumlandırılmıştır.
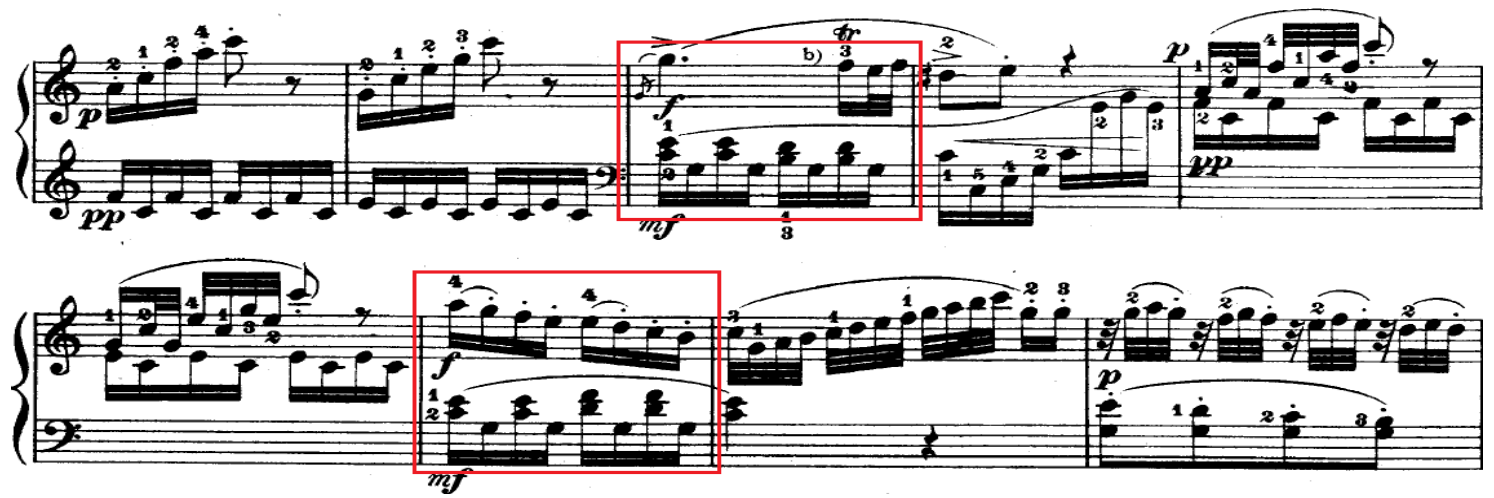

Şekil 11. Mozart Sonata in C Majör K.330

Figure 11. Mozart Sonata in C Majör K.330)

Yukarıda Şekil 11'de, Mozart K.330 Do Majör Sonat'ın birinci bölümünün 5. ve 13. Ölçüler arası görülmektedir. Yapı 6'nın kullanıldığı ölçüler kırmızı renk ile belirtilmiştir. Bu eserde yapı 6'nın kullanımı, Şekil 10'daki gibi sürekli olarak değil belirli özel bölgelerde kullanılmıştır. Ancak eserin sol eldeki diğer ölçülerinde dikkatıice bakıldığında yapı 6'nın daraltılarak da kullanıldığı görülmektedir. Bu alanlar yeşil renk ile belirtilmiştir. 
Tablo 8. Yapı 7'nin durumu

(Table 8. Status of building 7)

\begin{tabular}{|c|c|c|c|c|c|c|c|c|c|}
\hline \multicolumn{2}{|r|}{ Yapı 7} & \multirow{2}{*}{$\begin{array}{c}\text { Şifre } \\
\text { T }\end{array}$} & \multirow{2}{*}{$\begin{array}{l}(f) \\
35\end{array}$} & \multirow{2}{*}{$\frac{\left(\frac{\circ}{0}\right)}{40,70}$} & \multicolumn{2}{|r|}{ Yapı 7} & \multirow{2}{*}{$\frac{\text { Şifre }}{\text { D } 7}$} & \multirow{2}{*}{$\frac{(\mathrm{f})}{4}$} & \multirow{2}{*}{$\begin{array}{c}\frac{(\%)}{\circ} \\
4,65\end{array}$} \\
\hline A & $\frac{1}{0 \cdot 0}$ & & & & $\mathrm{E}$ & 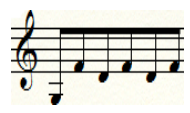 & & & \\
\hline B & $\sum_{0+1}+\frac{1}{0}$ & D 6 & 28 & 32,56 & F & $\frac{b_{0}}{b_{0}}$ & $\begin{array}{r}\mathrm{D} 6 \\
5\end{array}$ & 3 & 3,49 \\
\hline C & 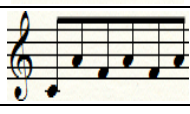 & $\begin{array}{r}S 6 \\
4\end{array}$ & 9 & 10,47 & $\mathrm{H}$ & tancen & $\begin{array}{r}\mathrm{D} 4 \\
3\end{array}$ & 2 & 2,33 \\
\hline D & $\frac{b}{7 \neq \%}$ & D 7 & 5 & 5,81 & & Toplam & & 86 & $\div 100$ \\
\hline
\end{tabular}

Tablo 8'de, Yapı 7'nin yedi farklı şekilde konumlandığı görülmektedir. Konumların şifreleri incelendiğinde, T (Tonik) ve D-6 (Dominant altılı)'nın ilk iki sırada olduğu görülmektedir. $\quad$ D $4-3$ (Dominant üç-dört) konumunun en az sayıda kullanıldığı görülmektedir. D 6-5 (dominant beş-altı) ile iki farklı biçimde kullanılan D-7 (Dominant yedili) konumlarının ise az sayıda kullanıldıkları göze çarpmaktadır. Yapı 7'nin ileri düzey sonatlarda kullanımına örnek aşağıda sergilenmiştir.
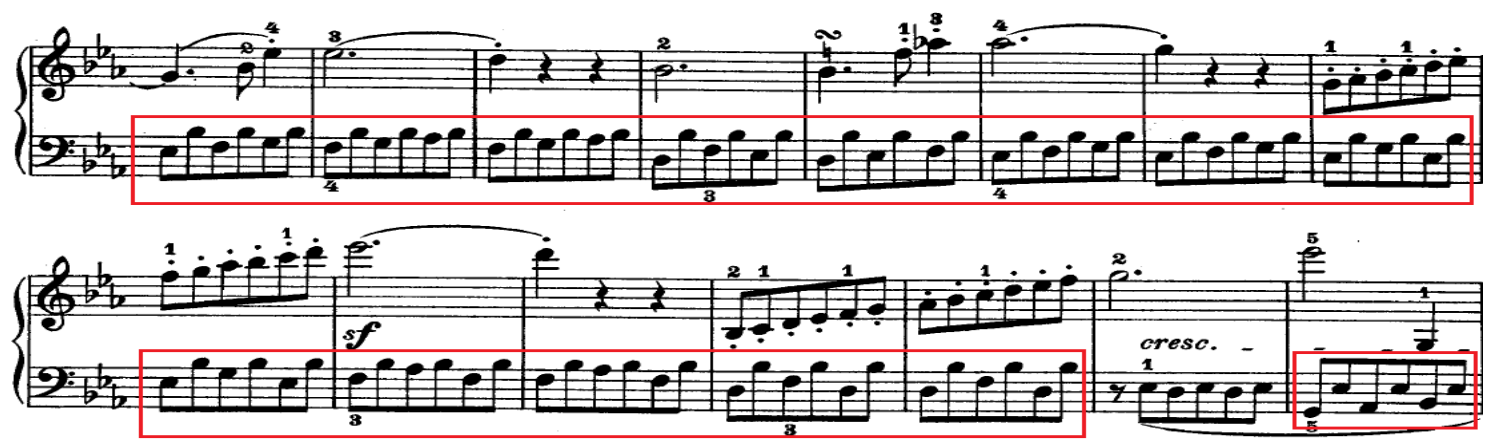

Şekil 12. Beethoven Sonata Op.10 No.1

(Figure 12. Beethoven Sonata Op.10 No.1)

Yukarıda Şekil 12'de, Beethoven Op.10 No.1 Piyano Sonatı'nın 1.bölümünün 57. ve 71. Ölçüler arası sergilenmektedir. Yapı 7'nin kullanımı bu sonatta farklı bir şekilde olmuştur. Bu fark her ölçüde ikinci ve üçüncü zamanlarda çoğunlukla farklı notalar kullanılarak eşlik yapısı ezgiselleştirilmiştir.

Tablo 9. Yapı 8'in durumu

(Table 9. Status of building 8)

\begin{tabular}{|c|c|c|c|c|c|c|c|c|c|}
\hline \multicolumn{2}{|c|}{ Yapı 8} & Şifre & $(f)$ & $\left(\frac{\circ}{0}\right)$ & \multicolumn{2}{|r|}{ Yapı 8} & \multirow{2}{*}{$\begin{array}{l}\text { Şifre } \\
\text { D } 7\end{array}$} & \multirow{2}{*}{$\begin{array}{c}(f) \\
4\end{array}$} & \multirow{2}{*}{$\frac{\left(\frac{\circ}{8}\right)}{4,82}$} \\
\hline A & $\frac{\operatorname{la}_{0}}{0_{0}}$ & $\mathrm{~T}$ & 36 & 43,37 & D & $\frac{\theta_{7} \sqrt{7}}{2 \sqrt{2}}$ & & & \\
\hline B & $\frac{1}{D_{0}+\ldots}$ & D 6 & 22 & 26,51 & $E$ & $\frac{7=6}{0 \neq 0}$ & D 7 & 4 & 4,82 \\
\hline C & 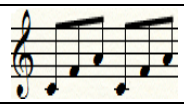 & $\begin{array}{r}\text { S6 } \\
4\end{array}$ & 14 & 16,87 & $\mathrm{~F}$ & $b_{i+\infty}$ & $\begin{array}{r}\text { D6 } \\
5\end{array}$ & 3 & 3,61 \\
\hline & & & & & & Toplam & & 83 & $\div 100$ \\
\hline
\end{tabular}


Tablo 9'da, Yapı 8'in altı farkıı Şekilde konumlandığı görülmektedir. Konumların şifreleri incelendiğinde, $T$ (Tonik) ve D-6 (Dominant altılı)'nın ilk iki sırada olduğu görülmektedir. İki farklı biçimde ve aynı oranda kullanılan D-7 (Dominant yedili) konumları ile D 6-5 (Dominant beş-altı) konumunun ise az sayıda kullanıldığı göze çarpmaktadır. Yapı 8'in ileri düzey sonatlarda kullanımına örnek aşağıda sergilenmiştir.
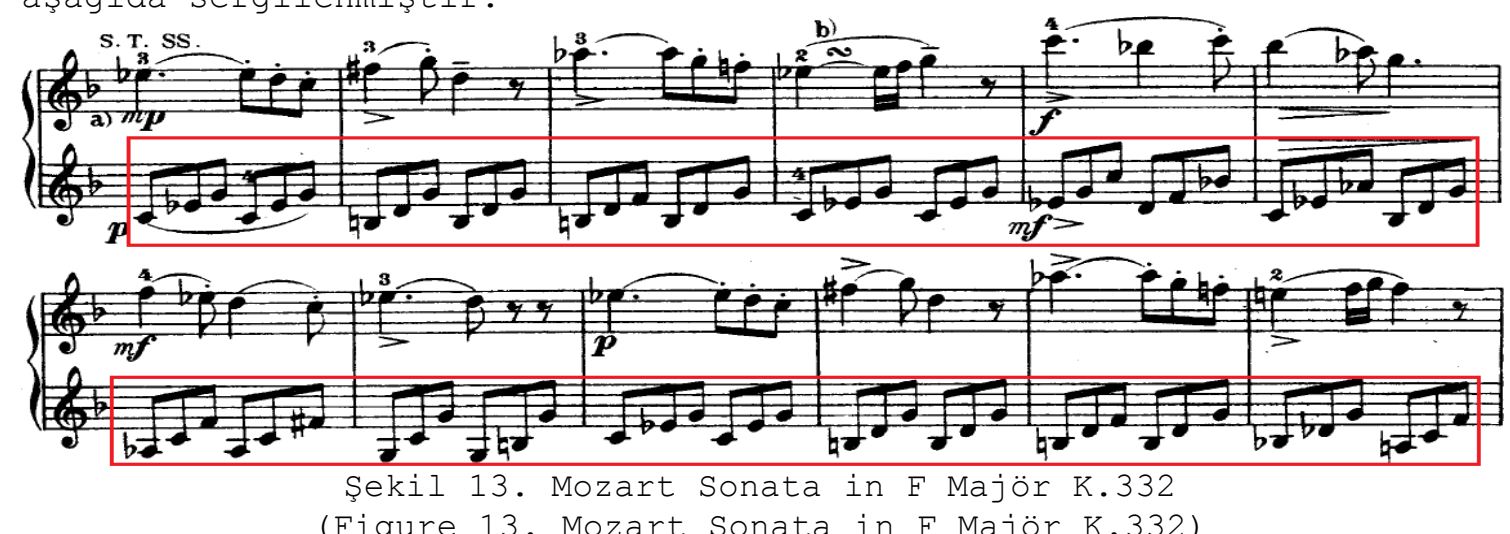

Yukarıda Şekil 13'de, Mozart K.332 Fa Majör Sonat'ın 3.bölümünün 50. ve 61.ölçüler arası sergilenmektedir. Sonatın bu kısmında Yapı 8'in olduğu gibi kullanıldığı göze çarpmaktadır. Özelıikle farklı tonlarda ve konumlarda kullanımı, eser içerisinde bu yapının ne denli önem taşıdığını göstermektedir.

Tablo 10. Yapı 9'un durumu

(Table 10. Status of building 9)

\begin{tabular}{|c|c|c|c|c|c|c|c|c|c|}
\hline \multicolumn{2}{|r|}{ Yapı 9} & Şifre & (f) & $\left(\frac{\circ}{0}\right)$ & \multicolumn{2}{|c|}{ Yapı 9} & \multirow{2}{*}{$\frac{\text { Şifre }}{\text { D7 }}$} & \multirow{2}{*}{$\frac{(\mathrm{f})}{6}$} & \multirow{2}{*}{$\frac{\left(\frac{0}{0}\right)}{12,24}$} \\
\hline A & $\begin{array}{llll} & & \\
0 & 0 & & \end{array}$ & $\mathrm{~T}$ & 24 & 48,98 & D & \begin{tabular}{|l|l|} 
\\
$\frac{1}{2}$
\end{tabular} & & & \\
\hline B & $\frac{b \cdot 2}{2: 2}$ & $\begin{array}{c}\text { S } 6 \\
4\end{array}$ & 10 & 20,41 & $E$ & $f_{0}+\ldots$ & $\begin{array}{c}\text { D4 } \\
3\end{array}$ & 2 & 4,08 \\
\hline $\mathrm{C}$ & $f_{0+2}$ & D 6 & 7 & 14,29 & & Toplam & & 49 & $\frac{0}{0} 100$ \\
\hline
\end{tabular}

Tablo 10'da, Yapı 9'un beş farklı şekilde konumlandığı görülmektedir. Konumların şifreleri incelendiğinde, T (Tonik) ve S6/4 (subominant dört-altı)'nın ilk iki sırada olduğu görülmektedir. D-6 (Dominant altılı), D7 (dominant yedili) ve D4/3 (Dominant üç-dört) konumlarının ise az sayıda kullanıldığı göze çarpmaktadır. Yapı 9'un ileri düzey sonatlarda kullanımına örnek aşağıda sergilenmiştir. 

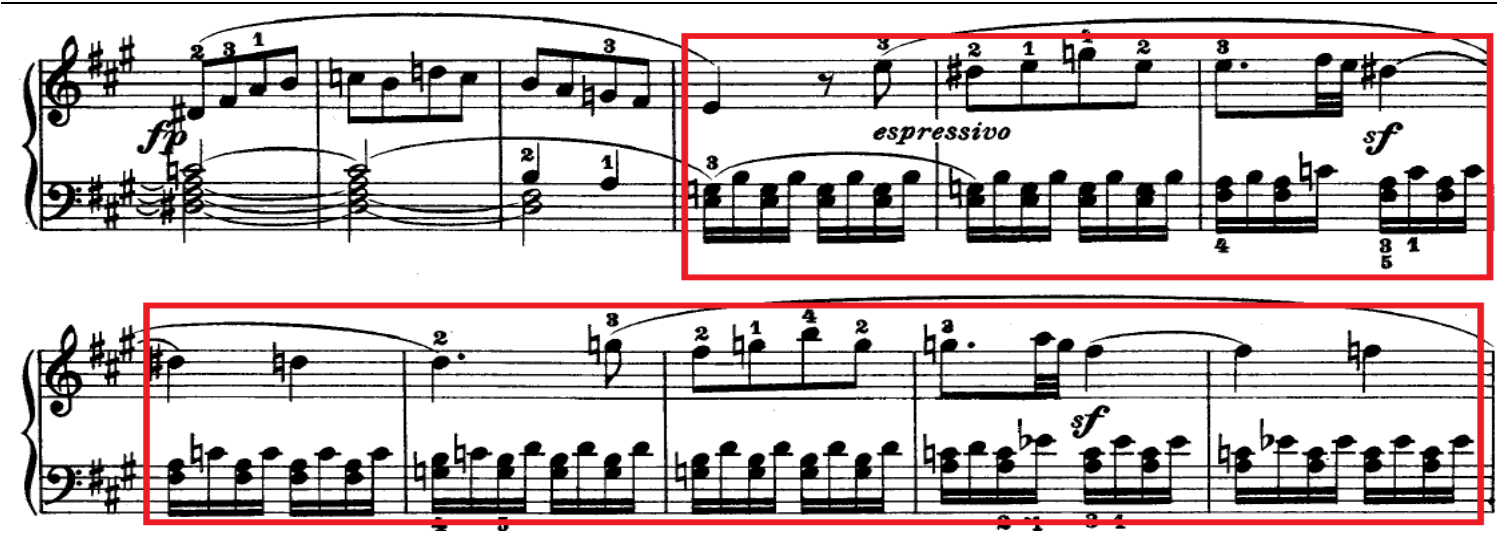

Şekil 14. Beethoven Sonata Op.2 No.2

(Figure 14. Beethoven Sonata Op.2 No.2)

Yukarıda Şekil 14'de, Beethoven'in Op.2 No.2 Piyano Sonatı'nın birinci bölümünün 56. ve 66. Ölçüler arası görülmektedir. Şekil üzerindeki kırmızı alanla işaretlenen kısımda Yapı 9'un onaltılık ritim şeklinde kullanıldığı görülmektedir. Bu eserde, yapı 9'un kullanım tekniği aynı kalmasına rağmen yapının ritmi değiştirilerek esere uygun şekle büründürülmüştür.
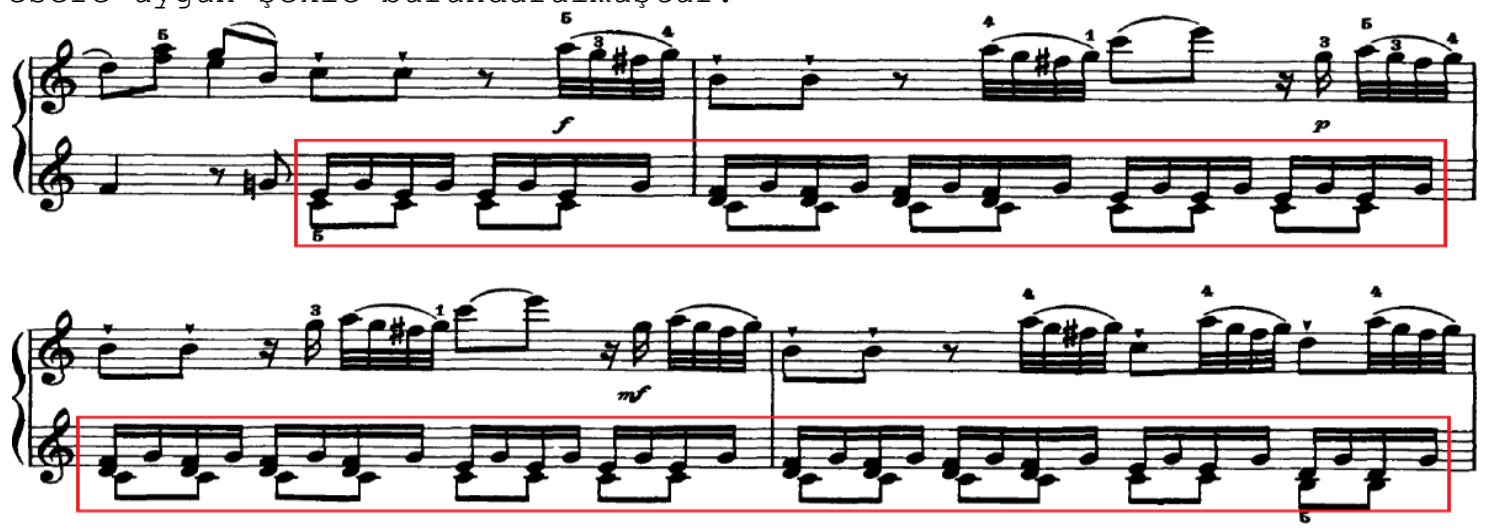

Şekil 15. Haydn Sonata in C Majör No.50

(Figure 15. Haydn Sonata in C Majör No.50)

Yukarıda Şekil 15'te, Haydn'ın No.50 Do Majör Sonatı'nın 10. ve 13. Ölçüler arası görülmektedir. Bu eserde Yapı 9'un kullanımı kırmızı alan içerisinde gösterilmiştir. Şekil 15'deki iki, üç ve dördüncü ölçülerin sol el yapılarına bakıldığında Yapı g'un genişletildiği görülmektedir. Birinci ölçüde bulunan yapının aksine diğer ölçülerde $(2,3$, ve 4) her ritim kümesinin ilk zamanı üç sese çıkartılmıştır. Bu şekilde yapı daha fazla ses rengine sahip olmuştur.

Tablo 11. Yapı 10' un durumu

(Table 11. Status of building 10)

\begin{tabular}{|c|c|c|c|c|c|c|c|c|c|}
\hline \multicolumn{2}{|c|}{ Yapı 10} & Şifre & (f) & $\left(\frac{0}{0}\right)$ & \multicolumn{2}{|c|}{ Yapı 10} & Şifr & (f) & $\left(\frac{0}{0}\right)$ \\
\hline A & $t_{0}$ & $\mathrm{~T}$ & 13 & 59,09 & $\mathrm{C}$ & $\frac{2}{2}$ & D 7 & 2 & 9,09 \\
\hline B & 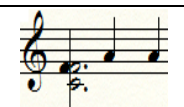 & $\begin{array}{r}\text { S } 6 \\
4\end{array}$ & 6 & 27,27 & D & $\frac{7+2}{3}$ & D 7 & 1 & 4,55 \\
\hline & & & & & & Toplam & & 22 & $\div 100$ \\
\hline
\end{tabular}


Tablo 11'de, Yapı 10'un dört farklı şekilde konumlandığı görülmektedir. Konumların şifreleri incelendiğinde, T (Tonik) konumunun yoğun olarak kullanıldığı görülmektedir. S 6-4 (Subdominant dört-altı) konumunun ikinci sırada olduğu görülmektedir. İki farklı biçimde kullanılan D-7 (Dominant yedili)'nin ise en az sayıda kullanılan konumlar olduğu göze çarpmaktadır.

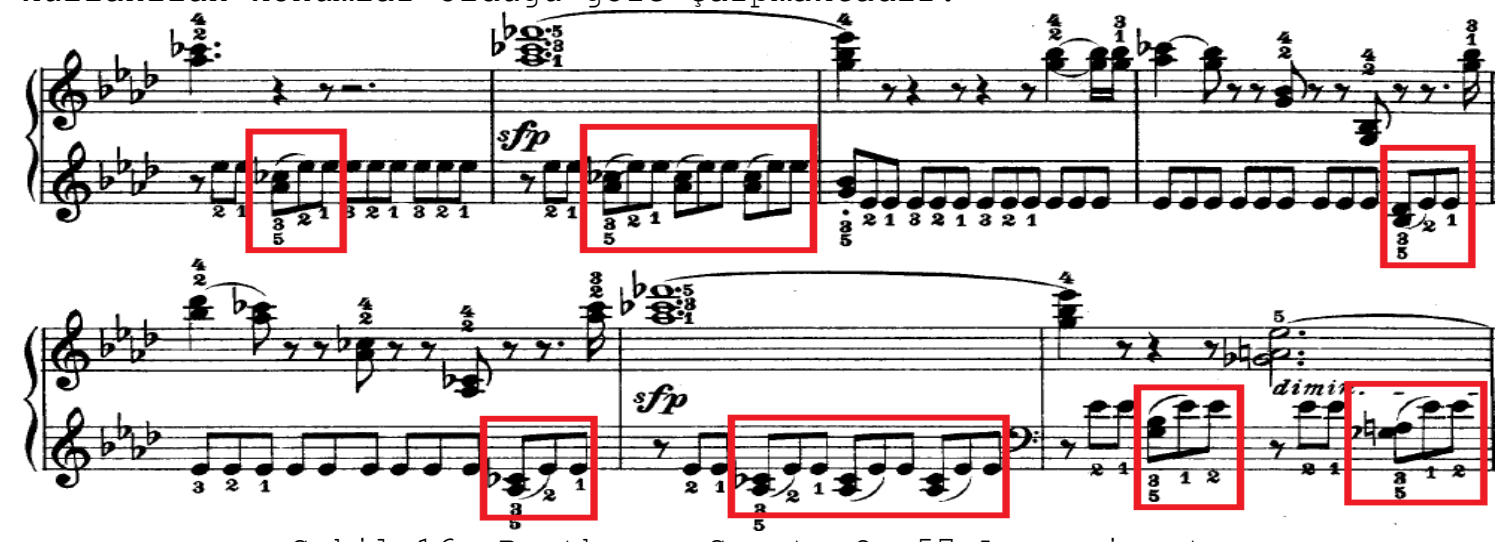

Şekil 16. Beethoven Sonata Op.57 Appassionata

(Figure 16. Beethoven Sonata Op.57 Appassionata)

Yukarıda Şekil 16'da, Beethoven Op.57 Appassionato Piyano Sonatı'nın 26. ve 32. Ölçüler arası görülmektedir. Yapı 10'un kullanıldığı yerler kırmızı alan ile işaretlenmiştir. Yapı 10'un ana kalıbı ile bu eserde kullanılan kalıp arasındaki fark ilk zamanın uzamamasıdır. Burada önemli olan yapının olduğu gibi kullanılmasının dışında farklı bir biçimde kullanılabilir olmasıdır. Ayrıca Şekil 16'dan anlaşılacağı üzere, Yapı 10 sürekli değil gerekli görülen yerlerde kullanılmıştır.

Tablo 12. Yapı 11'in durumu

(Table 12. Status of building 11)

\begin{tabular}{|c|c|c|c|c|c|c|c|c|c|}
\hline \multicolumn{2}{|r|}{ Yapı 11} & Şifre & $(\mathrm{f})$ & $\left(\frac{0}{0}\right)$ & \multicolumn{2}{|c|}{ Yapı 11} & \multirow{2}{*}{$\begin{array}{c}\text { Şifre } \\
\text { S6 } \\
4\end{array}$} & \multirow{2}{*}{$\frac{(f)}{2}$} & \multirow{2}{*}{$\frac{(\%)}{10,00}$} \\
\hline A & $\frac{1}{2}$ & $\mathrm{~T}$ & 8 & 40,00 & $\mathrm{C}$ & $\frac{15 \cdot c}{b \cdot 2}$ & & & \\
\hline B & $\frac{b}{b+1}$ & D 6 & 8 & 40,00 & D & $\frac{}{b_{7}}$ & D 7 & 2 & 10,00 \\
\hline & & & & & & Toplam & & 20 & $\frac{0}{100}$ \\
\hline
\end{tabular}

Tablo 12'de Yapı 11'in dört farklı şekilde konumlandığı görülmektedir. Konumların şifreleri incelendiğinde, ilk sırada yer alan $\mathrm{T}$ (Tonik) ve D-6 (Dominant altılı) konumlarının aynı oranda kullanıldığı göze çarpmaktadır. Yine aynı oranda kulıanılan S 6-4 (Subdominant dört-altı) ile D-7 (Dominant yedili) konumları ise az oranda kullanılmıştır. 

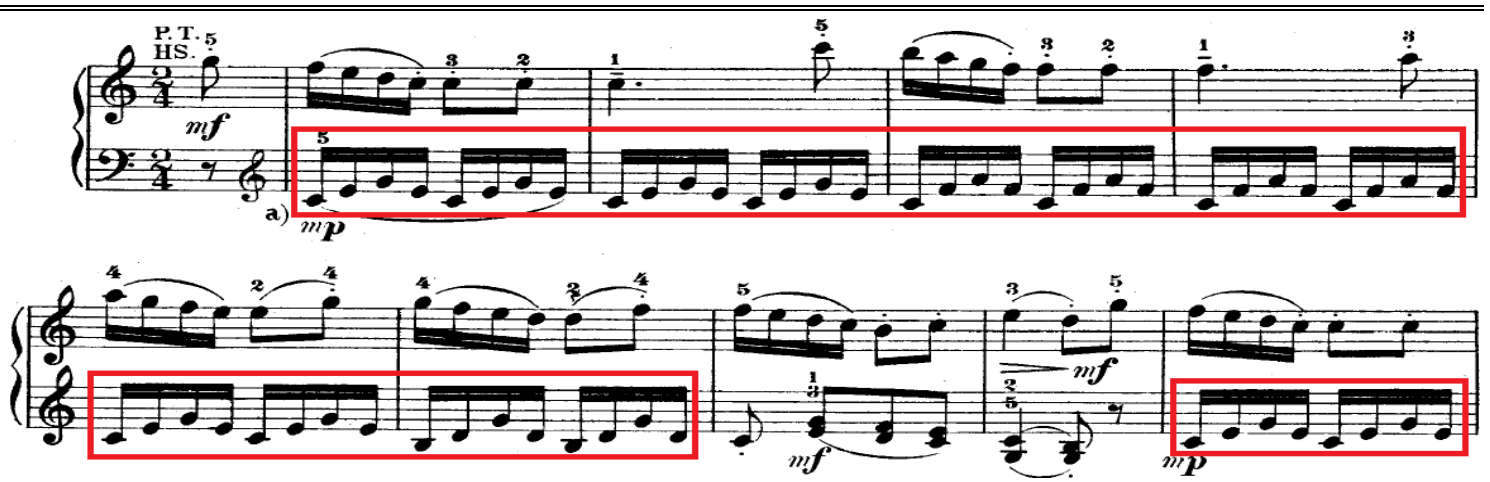

Şekil 17. Mozart Sonata in C Majör K.309

(Figure 17. Mozart Sonata in C Majör K.309)

Yukarıda Şekil 17'de Mozart K.339 Do Majör Sonat'ın 3.bölümü sergilenmiştir. Yapı 11'in bu eserde kullanımı kırmızı alan içerisinde gösterilmiştir. Yapı 11 ile eserde kullanılan yapı arasındaki fark sadece ritim açısındandır.
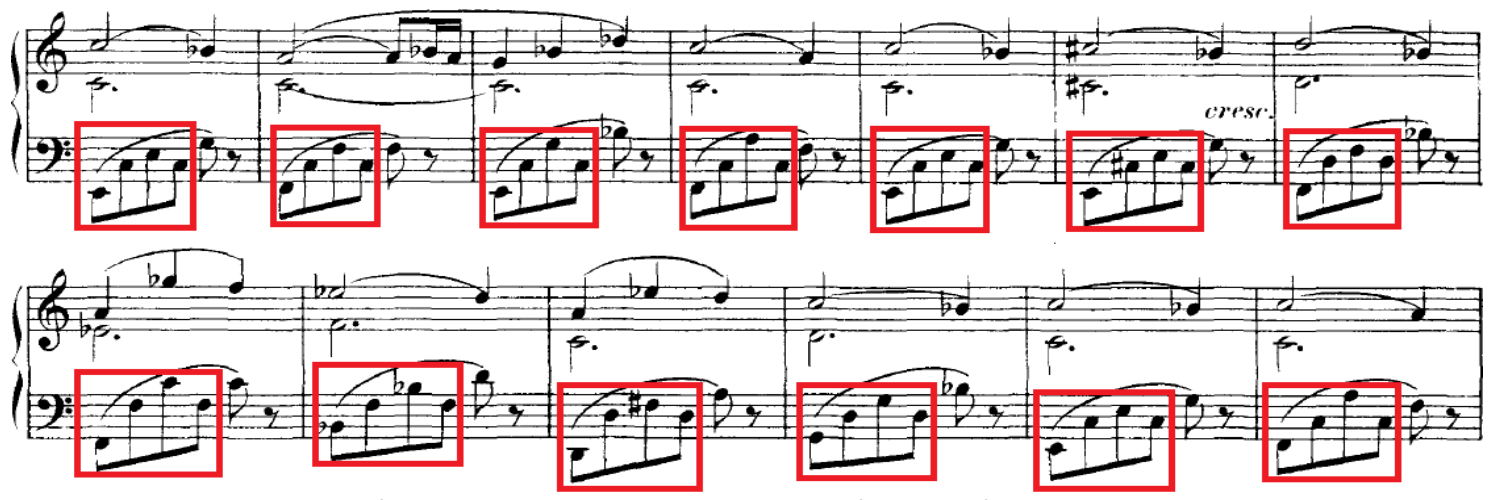

Şekil 18. Schubert Sonata in A Minör D.784

(Figure 18. Schubert Sonata in A Minör D.784)

Yukarıdaki Şekil 18'de, Schubert D.784 La Minör Sonat'ta Yapı 11'in ses olarak genişletilmiş bir kullanımı açıkça görülmektedir. Piyano edebiyatında bu şekilde birçok eşlik yapısının ses sınırının daraltılıp ya da genişletilip kullanımına sıkça rastlamak olasıdır. Bu tür kullanımlar o eser için daha etkin bir eşlik yapısı, ezgi zenginliği, zor fakat daha estetik bir teknik yapr ve dolgun bir armoni sağlamaktadır.

\section{SONUÇLAR VE ÖNERİLER (RESULTS AND SUGGESTIONS)}

Bu bölümde araştırmada elde edilen bulgulara dayanılarak ulaşılan sonuçlar ve bu sonuçlara bağlı olarak geliştirilen öneriler yer almaktadır.

\subsection{Sonuçlar (Results)}

- Carl Czerny'nin Op.599 Etudes etüt kitabında kullanılan yapıların sol elin gelişimi açısından oldukça önemli olduğu,

- En temel piyano parçalarından, ileri seviyede eserlere kadar birçok bestede karşılaşılabilecek yapılar üzerine hazırlanmış olduğu,

- Orta ve ileri düzey piyano eserlerinde (sonat, sonatin, valse vb.) kullanılan yapıların sıklıkla kullanıldığı,

- Piyanoda önemli bir görev üstlenen, eserin armonik yapısını gösteren akorlara yönelik çalışmaların bulunduğu, 
- Kullanılan yapıların farklı eserlerde farklı ritmik yapılar ile de kullanılabildiği,

- Üçleme gibi farklı yapılar şeklinde karşılaşılabileceği ve kullanılan yapı şekilleri ile eserlerde kullanılan zamanın etkin bir biçimde ifade edilebildiği,

- Bestecinin eser yazma anlayışına ya da yazdığı eserin biçimine göre kalıplaşmış bazı yapılarda çeşitlemelerin kullanılabildiği,

- Bu yapıların eser içinde, farklı zamanlarında farklı notalar kullanılarak eşlik yapısının ezgiselleştirilebildiği,

- Eserler içinde sıkılıkla kullanılan bazı yapıların, yapının önemini gösterdiği,

- Eserler içinde yapının kullanım tekniği aynı kalmasına rağmen ritmi değiştirilip esere uygun şekle büründürülerek kullanılabildiği,

- Yapıların bazı ölçülerde genişletilerek kullanıldığı ve bazı ölçülerde ritim kümelerinin ilk zamanı üç sese çıkartılarak yapının daha fazla ses rengine sahip olabilmesinin sağlandığı,

- Yapıların, eserler içinde sürekli değil ama gerekli görülen yerlerde kullanıldı ̆̆ı,

- Piyano edebiyatında birçok eşlik yapısının ses sınırının daraltılıp ya da genişletilip kullanımlarına sıkça rastlanabileceği ve bu tür kullanımların eser için daha etkin bir eşlik yapısı, ezgi zenginliği, zor fakat daha estetik bir teknik yapı ve dolgun bir armoni sağladığı gözlenmiştir.

\section{2. Öneriler (Suggestion)}

- Piyano eğitimi sürecinde öğrenilmiş teknik ve teorik bilgilerin basit olmasının o bilgilerin önemini azaltmadığı ve basit olarak önemsenmeyen bilgilerin ileride karmaşık durumlara çözüm olacağı bilinmeli,

- Çalışlan her etüt anlamlı bir şekilde irdelenmeli ve etütten elde edilen basit kazanımların ileriki seviyelerde çok büyük önem taşıyacă̆ı unutulmamalı,

- Etütler sadece deşifre amacı ile çalınmamalı, etütlerin içerisinde bulunan ve çalmakta zorlanılan yapılar kendi içerisinde etütleştirilmeli (etütten etüt tasarlama gibi),

- Öğrenilen en basit bir akor yapısını (ör: do-mi-sol, sol el parmak no:5-3-1, sağ el parmak no:1-3-5) ileride karşılaşılabilir düşüncesinden hareket ile farklı tonlarda uygulamalı,

- Sadece etüt çalışmalarında değil aynı zamanda piyano eserlerine çalışılırken bile öğrenilen yapılar yine karşılaşılacakmış düşüncesi ile önemsenmelidir.

\section{KAYNAKLAR (REFERENCES)}

1. Bağçeci, S.E., (2003). Piyano Eğitiminde Müzikal Analiz Kavramı - Kapsamı ve Örnek Klavye Analizleri. Fırat Üniversitesi Sosyal Bilimler Dergisi. Cilt: 13, Sayl:1, ss: 162.

2. Czerny, C., Il Primo Maestro Di Planoforte 100 Studi Gıornalıerı Op. 599. Ricordi.

3. Cüceoğlu, G. ve Berki, T., (2007). Flüt Eğitimine Yönelik Bir "Etüd Analiz Modeli". GÜ, Gazi Eğitim Fakültesi Dergisi. Cilt: 27, Say1: 1, SS: 228, ISSN: 1301-9058.

4. Delikara, A., (2013). Keman Eğitimine Yönelik Bir "Etüt Analiz Modeli". www.sanategitimidergisi.com. Cilt: 1, Sayl: 2, ss: 117, DOI:10.7816/sed-01-02-01. 
5. Ercan, N., (2008). Piyano Eğitiminde İlke ve Yöntemler. Ankara: Sözkesen Matbaacılık. ss: 95.

6. Kurtuldu, K., (2009). Czerny Op. 29930 Numaralı Etüde Yönelik Teknik ve Biçimsel Analiz. Mehmet Akif Ersoy Üniversitesi Sosyal Bilimler Enstitüsü Dergisi. Yıl:1, Sayı:1, Güz, ss: 29, ISSN: 1309-1387.

7. Öztürk, B., (2007). Carl Czerny'nin opus 299/19 Numaralı Etüdünün Piyano Eğitimine Yönelik Analizi. Gazi Üniversitesi Gazi Eğitim Fakültesi Dergisi. Cilt: 27, Sayı:2, ss: 242-243, ISSN : 1301-9058.

8. Pamir, L., (Bilinmeyen Tarih). Çağdaş Piyano Eğitimi. İstanbul: Beyaz Köşk (Müzik Sarayı) Yayınları. ss: 130.

9. Say, A., (2002). Müzik Sözlüğü. Ankara: Müzik Ansiklopedisi Yayınları (189-190).

10. Temiz, E., (2006). Panofka 24 Vocalizzi Etüt Kitabında Yer Alan 2 No'lu Etüt Analizi. Türk Eğitim Bilimleri Dergisi. Güz, Cilt: 4, Sayı: 4, ss: 397-407.

11. Tufan, E., (2004). Geleneksel Makamlar Kullanılarak Yazılan Etütlerin Piyano Eğitimi Açısından Önemi. Gazi Üniversitesi Gazi Eğitim Fakültesi Dergisi. Cilt: 24, Sayı:2, ss: 76, ISSN: 13019058.

12. Umuzdaş, M.S., (2012). Carl Czerny Opus 29934 Numaralı Etüdün Teknik ve Armonik Analizi. International Journal of Human Sciences [Online]. Cilt:9, Sayl: 2, ss: 1569-1580, ISSN: 13035134 . 